\title{
Revisiting the practice of Bible-translation: The need to engage ordinary believers when translating the Psalms
}

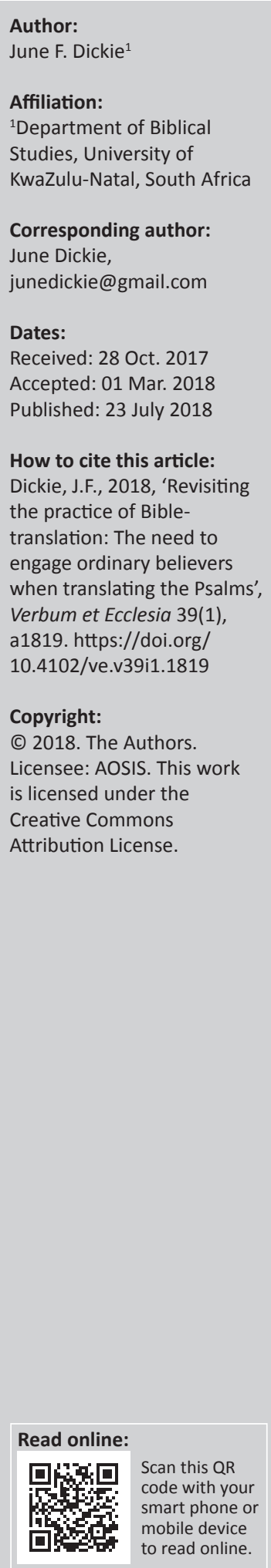

Many young isiZulu speakers find the 1959 Bible translation difficult to read and understand. However, they are interested in getting inside the black box of Bible translation, and being participants in the process. Moreover, they have a culture of composing and performing poetry, which lends itself to their involvement in the translation and performance of biblical poetry. An experimental study sought to see if Zulu youth could compose translations of some praise psalms and perform them such that the community would accept them as 'biblical material', and relevant and engaging for young people. The methodology was to invite interested persons to participate in workshops that provided basic training in Bible translation, features of oral communication and performance, Zulu and biblical poetry and Zulu music. The participants then made their own translations of some short psalms, and performed them as songs, rap or spoken poetry items. The results suggest several benefits that could be replicated in other situations and with other language groups. These include new, vibrant ways to share Scripture, and a means for individuals to engage with the Scriptures and 'own' the translation. In conclusion, there is an open door for 'ordinary' members of the community (especially those interested in poetry and music) to contribute significantly to poeticallybeautiful and rhetorically-powerful translations of biblical psalms. Moreover, the experience they gain will not only support the discipleship ministry of the church, but also its outreach to other young people, drawing them in by engaging and relevant performances of the biblical message.

Intradisciplinary and/or interdisciplinary implications: This study challenges the traditional perspectives of Bible translation and Practical Theology, suggesting that 'ordinary' members of the community can enrich the translation of biblical poetry, and their engagement in the process can have many positive outcomes in terms of church ministry.

\section{Introduction}

The Scriptures available to isiZulu-speaking christians are very limited: essentially, the only version widely available is that of 1959 (or reprints thereof). This translation follows the formal equivalence approach to Bible translation, and thus is something like the King James Version (KJV), using archaic language and grammatical structures that are not easily understood. Even the 1986 New Testament and Psalms ${ }^{1}$ uses words that are not intelligible to educated Zulu Christians today. ${ }^{2}$

The translation of the psalms was also made without a sensitivity to the aesthetics of Zulu poetry or the functions of the poetic features in the Hebrew text. The renowned Bible translation scholar, Nida (2003:82), notes that a Zulu poet complained of the poor poetry in the isiZulu psalms, and requested permission to revise them, to make them more acceptable poetically. According to Nida, he did so, 'with great success', making use of the tradition of Zulu izibongo [praise poetry]. ${ }^{3}$

A third factor calling for a new approach is the ignorance of many young Zulu people concerning the Scriptures, in particular the Psalms. In non-liturgical churches, the psalms are rarely if ever 1.This translation was produced by the Bible Society (although it is not freely available, as it was not well received).

2.A third-year Biblical Studies student and a lecturer at a theological institute did not understand some words in Psalm 93 (1986), for example, 3c: imifula ihlobe ngesimokololo.

3.Unfortunately, Nida did not give any reference for this poet, but it is possible that it was Bethuel Blose Ndelu, a Lutheran schoolteacher and poet, who later became one of the translators on the 1986 BSSA revision. 
read or used as the sermon text, and many young isiZulu speakers have never read them and are not aware that they are poems that were originally sung. My recent (Dickie 2017) study shows that many participants are surprised that the Bible includes poetry, indeed poetry that is full of emotions with which they can identify.

Apart from these three reasons calling for 'something new' to help Zulu believers in their faith, there is also the need to reach unchurched people in a more effective way. Many young people, even within the church, find the conventional ways of presenting the biblical message boring or irrelevant. Part of this is because the 'Scripture reading' is not easy to understand, and is often read badly (with the difficult isiZulu orthography). Those trying to follow the reading, by engaging with the written text, also battle. One reason for this is that the post-1994 generation seems to read and write 'light Zulu', whereas the 1959 Scriptures contain many 'deep Zulu' words. Although young isiZulu speakers may be able to understand and even speak some deep Zulu, the dominance of English in their post-1994 education has meant that few of them can read the symbols for clicks or difficult consonant clusters. Those who are trying to listen and hear the Scriptures being read also struggle as the 1959 translation was not prepared with an aural audience in mind. It does not take cognisance of the features of oral communication, which would enable listeners to hear the text clearly and to remember it.

\section{Methodology and results A research study}

Four areas of recent research speak to the needs mentioned above. These are discussed further in the section 'Theoretical basis for research', providing the theoretical basis for the empirical study underlying this article. The empirical work is fully described in Dickie (2017) but essentially the methodology consisted in inviting isiZulu speakers interested in poetry and/or music to participate in a workshop. Over three to four days, they explored principles of Bible translation, poetry, music, orality and performance, with a view to making their own translations of three short psalms, and then performing them as a song or spoken poetry item. The teaching input varied according to the amount of time available (as not all participants attended the full programme). The greatest need was to help participants understand the approach to translation being sought, that is, not word-forword but meaning-based and culturally sensitive. Participants then learned how to work with a Hebrew interlinear text, and to recognise the repetitions apparent in the original (particularly repetitions of words or phrases).

Other poetic issues were also discussed for example, the use of certain metaphors in the original Hebrew, which might not be relevant in the local context. ${ }^{4}$ Poetic structures (such as parallelism and chiasm) in the Hebrew text were noted, and

4.For example, Psalm 93:3 refers to 'waves/rivers' which for Zulus living in Pietermaritzburg (PMB) is not a real threat. Hence, they were encouraged to find other metaphors that symbolised to them 'fearful things'. Many used the metapho of wind or a lion to represent problems or difficulties. examples of similar such structures in Zulu praise poetry were given. The meaning of key terms needed to be clarified (e.g. 'righteousness' or 'glory') as did the function of the grammatical structures in the Hebrew: for example, the use of a vocative to slow down the text, the use of a collocation of similes to express an intense form of the attribute, ${ }^{5}$ or the repetition of words in different parts of the psalm, to unite the poem as a whole. Participants were encouraged to use the same device in isiZulu (if appropriate), or another device that would perform the same function. The latter clearly required more creativity, but some participants $C$ succeeded. ${ }^{6}$

Attention was also given to features of oral communication (in contrast to those of written text). These included those mentioned by Wendland (2006:43) and listed in footnote 12 . When time permitted, the features of Zulu music were discussed. These included the use of call-and-response, harmony, the melody of the speech and the melody of the music, the need for a new melody for new words and different rhythm patterns. Participants who were musically gifted did not need any help in converting their translations into songs. On the other hand, those who were more 'wordsgifted' had no interest in making a song, but performed their item as rap or slam poetry. In some cases, poets and musicians combined to give a performance that included song and spoken word or rap.

The first day of the workshop all of the four areas mentioned above were covered, and participants then worked on their own translation of Psalm 134. Although this praise psalm has only three verses, it displays interesting poetic features (repetition, chiasm, an attention-getter in the first verse and a focus on the third verse). All participants succeeded in making a reasonably accurate translation and putting it into a performance style. Many of the songs were very singable with a good rhythm. One poet changed the beat before the key verse (v.3), thereby giving focus to it.

On the second day of the workshop, the above theory was briefly repeated and then applied to Psalm 93. This psalm shows several wonderful poetic features: inclusion (in vv. 1-2 and 5), triple parallelism (in both v. 3 and v. 4) and strong metaphorical language (in vv. 3-4). Participants were encouraged to think outside the box in using a metaphor(s) that were meaningful to them in their context, as they indicated that the 'waves' (mentioned in the Hebrew) was not particularly relevant. Some maintained the same metaphor throughout the three cola of v. 3; others used a variety of metaphors (e.g. wind, waves and a lion). The use of 'mixed metaphors' is typical of slam poetry, popular among Zulu youth. The performances of this psalm included partsinging, with different voices singing the chorus (vv. 3-4) and the inclusion sections (vv. 1-2 and 5). Another group gave

5.For example, Psalm 145:5 uses 'the majesty of the glory of the splendour'. The three terms in Hebrew have very similar meanings, but their use together serves to intensify the attribute.

6.For example, in Psalm 134:3, one poet added (in parallel) a colon, to emphasise the key verse and to provide a good rhythm. 
prominence to the main verse (v. 4) by reciting it at the start, before entering into the rest of the psalm in a sung form.

The third day was similar to the second, with the theory being applied to Psalm 145:1-7. This psalm has a steady rhythm, a number of 'voices' and some complex key terms, but most participants coped very well with the challenge. Participants were then encouraged to select one or two songs to practice for a performance before the local church. A day was set aside for practising and perfecting the performances, and on the day, they were very well received.

Audience members were interviewed, as were some participants, and all of the latter group completed questionnaires to determine their experience of the workshop programme. The responses from the audience were very positive, seeing it as a fresh way of presenting the message, and an attractive way to draw those who would not otherwise be interested. The participants themselves seemed to take pride in their products (songs or poetry items), but even more so, were satisfied that they could participate in Bible translation and make a version that spoke to them and their peers. The process was more important than the product! This was an unexpected result.

\section{Theoretical basis for research}

The empirical study was based on recent research in four areas. First, the functional approach to Bible translation gives focus not only to communicating the meaning clearly, but also to including all the functions of the original text in the translation. For poetry, this is very important as the text not only communicates content, but also emotion, aesthetic beauty and rhetorical force (to persuade the listener or reader in a certain direction).

The second area of research that has application in this study is that of orality and performance studies. Scholars have noted the different ways of organising text in an oral community, where mnemonic devices are an integral part of the communication. A translation that utilises such oral and mnemonic devices will be heard more easily, and remembered.

Orality studies focus on the sound features of the communication, and performance studies add the visual and paralinguistic dimensions. Much of a message can be communicated through the tone of the voice, the volume and speed of delivery, the appearance of the messenger (clothes, facial expressions), gestures and other non-verbal features. Many scholars believe that the biblical message was originally 'performed', in that it was orally presented with all the possibilities of para-linguistic and extra-linguistic devices playing their part. Some researchers (e.g. Maxey 2009) are exploring the exegetical insights that emerge as the Scriptures are performed, and the original rich texture of the message is reclaimed.

Performance criticism also shows the impact of the audience on the content of the material presented, and the large part the audience plays in the acceptance or otherwise of the text. With their long history of oral art, Zulu audiences want, and expect, to be a part of the communication. Moreover, many Zulu youth (high school age and into the 20s) highly value participating in spoken poetry events (as performers or audience members). Poetry groups meet weekly in the towns and townships of KwaZulu-Natal, ${ }^{7}$ and this interest provides an open door to share the biblical message in an engaging and relevant way.

The third area of application for a fresh translation of some psalms is that of poetics. This is closely related to orality (mentioned above) as many oral features are poetic devices. But, in addition, other features (e.g. terseness of style) are typical of poetry, and Zulu poetry has certain other patterns that can be incorporated into a translation of biblical poetry.

Fourthly, as the psalms were originally composed to be sung, a study of ethnomusicology can contribute to a translation of psalms into a form that is easily singable. In the case of isiZulu translation, this requires an understanding of Zulu singing styles and rhythm in order to be able to perform the translation in a way that sounds like a good, Zulu song.

During my recent doctoral work (see Dickie 2017), I explored the literature in these four areas of study and applied it to the translation of selected praise psalms, using the form of Zulu poetics and Zulu musicality, and including members of the Zulu community in the translation and performance of these psalms. The results were very encouraging and show that 'ordinary' Zulu youth have the ability and interest to participate significantly in the Bible translation process. The benefits obtained in my study are referred to later in this article. Various practical difficulties that became evident suggest that future research should take advantage of another emerging opportunity, namely that of developments in technology.

These technological innovations continue to suggest new possibilities for reaching and teaching young people. Social media has become the dominant 'time spender' for many, including those in the Zulu community. Almost all young people have smartphones, and with the growing provision of 'Wi-Fi hot spots', the opportunity for them to go online, to learn and share or engage with others, is becoming a reality. Moreover, the interactive nature of communication today (as evidenced in social media and gaming) requires that discipleship needs to move in this direction too. The individual no longer wants to be dependent on others for his or her learning, and is not content to simply accept something that has been told to him or her, without going to the sources and exploring personally. Thus, the old way of teaching and discipling needs to take advantage of the new possibilities that are opening before us.

The theory underlying these four areas of study will now be considered in a summarised form.

7.For example, every Friday afternoon (13:30-14:30) about 150 young people press into the auditorium of the Pietermaritzburg city library to perform and listen to spoken poetry and musical items, all original compositions. 


\section{Translation studies}

Since ancient times, there has been a need for texts (oral or written) to be translated from one language to another. From the start, the question has been what kind of translation to produce: one that is literal (word-for-word), free or somewhere between the two extremes? Initially, a literal translation was considered to show greater fidelity to the original, but by the end of the 17th century, the translation of meaning was considered to be more faithful than the translation of the author's words (Munday 2001; 2010:24).

\section{As Nida and Taber (1969) note:}

The older focus in translating was the form of the message, and translators took particular delight in being able to reproduce stylistic specialities, e.g. rhythms, rhymes, plays on words, chiasm, parallelism, and unusual grammatical structures. The new focus ... has shifted from the form of the message to the response of the receptor... This response must then be compared with the way in which the original receptors presumably reacted to the message when it was given in its original setting. (p. 1)

This translation approach is known as 'dynamic equivalence'. It was later refined by de Waard and Nida (1986) to 'functional equivalence'. The goal in functional equivalence is to use functionally equivalent forms in the receptor language to match the functions of the source text, thereby requiring a new focus to the analysis of the source text (de Waard \& Nida 1986:36). Dynamic equivalence gives reference to only three communication functions, viz. informative, expressive and imperative (Nida \& Taber 1969:24-27), whereas functional equivalence incorporates five further functions of communication, viz. the cognitive, interpersonal, performative, emotive and aesthetic functions (de Waard \& Nida 1986:25). It is these latter functions that are particularly important in the translation of poetry.

In the 1970s and 1980s, functional theories of translation were emerging in Germany. Reiss (1984) and Nida (1960:195-199) both refer in their separate work to the concept of equivalence, focusing at the level of the text rather than the sentence. This took translation theory beyond the impact created by words to the communicative purpose of translation. These ideas were later developed by Vermeer (1989) into his highly influential Skopos theory. The 'skopos' is the purpose of the translation, determined by the setting, place, time and participants. ${ }^{8}$ In Skopos theory, the source text is 'dethroned' (Munday 2001, 2010:87), and the important factor is not 'equivalent meaning' but meeting the goal of the receptor text situation, that is, getting a 'functionally adequate result'.

Skopos theory can be controversial when the source text is Scripture because the function of the receptor text may not be the same as that of the source text. ${ }^{9}$ Munday $(2001,2010: 81)$

8. However, this notion was not entirely new. Nida and Taber (1969:1) had asked: 'Even the old question: 'Is this a correct translation?' must be answered in terms of the old question: 'Is this a co

9.For example, the skopos may be to provide meditations for the aged or stories for children, and the text may thus appear to be a 'paraphrase' rather than a 'translation'. also argues that 'Skopos theory does not pay sufficient attention to the linguistic nature of the source text'. Nord (1988) corrected these two criticisms; her functional, textlinguistic model considers the way the source text is organised at the sentence level and above, and shows greater fidelity to the original text.

Through the 1990s, an emphasis on linguistics persisted in translation theory, especially with the development of discourse analysis. Ernst Wendland (2002) argues that a literal approach is not suitable when translating a literary text that has artistic and rhetorical force:

The compositional procedure must be loosened up in order to allow gifted translators the freedom to more fully access and creatively utilise the stylistic and expressive resources of the receptor language. (p. 179)

Again, this is particularly relevant to the translation of poetry.

Cognitive and psycho-linguistic approaches were also proposed. One of the most useful was Relevance theory (posited by Sperber \& Wilson 1986). This was further developed by Gutt (1992), who argues that translation involves communication based on an interchange of inferences and interpretations. The cognitive environment of the receiver is considered, and then information is ideally communicated at minimum cost and maximum benefit to the recipient. To achieve 'minimum cost', redundancy may be necessary. As Nida (1964:182) notes: 'The maximising of redundancy reduces the work of decoding. At the same time, redundancy should not be so increased that the noise factor of boredom cuts down efficiency'.

The next development in translation theory was a focus on the aesthetic features of the text. Even in 1969, Nida and Taber (1969:148) had observed: 'Rhythmic features of poetry are highly valued for their special effects'. However, in general, not much attention has been given to the poetic, literary and rhetorical effects of texts. The person to lead the field in this area has been Wendland, with his study of Ruth in 1988, and many others since then. Over the past decade, he has developed his theory which he calls literary functional equivalence (or LiFE).

In the 1990s, there was a growing awareness that the majority of people hear the Bible being recited rather than read it themselves. Thus, attention was given to producing a Bible translation composed for the ear, one that could be understood easily when read aloud. Since then, interest has moved beyond audio translation to 'new media' translation (film and other multimedia performance, as well as virtual translations). Such 'new media' translations raise new issues and questions with regard to translation theory and practice. As Rowe (1999:51) observes, 'The translation theory that supports printed modern language versions of ancient texts may prove inadequate for the requirements of new media forms'.

In my study, the focus was on translating biblical poetry with a sensitivity to the sound and poetic features of the Hebrew 
text, and utilising the richness of the indigenous art contained within isiZulu, to produce a text that would stir the hearts of the receptor audience. The translation approach most suitable was thus the literary-rhetorical one, which focuses on phonic artistry and rhetorical power.

Weschler (1998:7) observes that: 'Like a musician, a literary translator takes someone else's composition and performs it in his own special way'. The Hebrew psalm, for example, is 'the composition', and literary translators apply their own feel for the music of the poetry, to produce a unique rendition. However, it must seek to move the audience in the same way as the composer intended, if it is to satisfy 'functional equivalence' which is foundational to literary translation.

Another aspect of literary translation is its ability to produce 'a rich chord instead of a single note' (Hargreaves 1993:137138). Lundin, Thiselton and Walhout (1999:169-171) note the same attribute when they describe literary translation as having 'multi-layered coding' that evokes various 'resonances, new perspectives'. Literary translation has the capacity to stir the imagination of the hearer, allowing him or her to participate in the evocation of images that are meaningful and emotive.

A literary translation utilises the sound dimension and thus should be orally performed, if it is to be received in its full glory. Thus, the features of oral communication and the dynamics of performance are next considered.

\section{Orality and performance studies}

Closely related to a focus on the literary and aural features of a text are its oral characteristics. This is not simply giving sound to printed text ${ }^{10}$; rather, the text must be completely restructured to be received by the ear and not the eye. As Euan Fry (1999:14) notes, oral discourse is very different from written discourse. ${ }^{11}$

Nida and Taber (1969:14) had noted that 'the Bible is often read aloud to a listening audience' and thus 'heard language should have priority over written language'. This is even more important today, both in the majority world where literacy remains very low, and in the modern world where books have been pushed aside by electronic media. In this regard, Scott (1999) asks: 'If sound is the medium of communication, then what are the implications for translation?'.

Moreover, in addition to many of the receptor cultures being predominantly oral, the source culture (that of the biblical world) was oral, and yet this is often ignored. As Bobby Loubser (2004:308) notes: 'It is an almost pervasive problem that in translation, primary oral texts are translated as if they were literary products'. Indeed, it is true that most modern

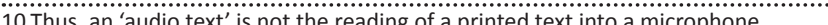

11.Luther sought to produce a German translation 'for the ear', to be read aloud in public worship. 'He constantly read his sentences aloud, testing the accents and cadences ... for their melodic flow' (Wendland 2012:19). translations have removed the oral features of the original languages. Thus, Rhoads (2012:25-27) argues that translation theory and practice requires a 'fundamental paradigm shift'.

Most Bible translators are highly literate and thus often unaware of how their literate way of communicating is not easily heard by the oral recipient. It is thus necessary for the translator to be aware of the styles of communication adopted by those who are (predominantly) oral. Wendland (2006:43) posits several such characteristics that if applied to the composition of the translation can greatly assist hearers to organise the text better in their minds. ${ }^{12}$

The interest in orality studies began with the work of Albert Lord and Milman Parry, studying oral epics in the 1960s. Then, Scribner and Cole (1981) and Ong (1982) did significant work in the area of literacy and orality. John Miles Foley (1995) extended the work begun by Parry and Lord, and moved the notion from 'orality' to 'performance'.

Performance includes paralinguistic and extra-linguistic features which communicate an important part of the meaning. Extra-linguistic features include gestures and other body language, dress and facial expressions. Paralinguistic features include features of the voice, such as the volume, speed of delivery, intonation and pausing. Foley (1995:87) notes that such 'paralinguistic cues are the very most perishable of keys to performance'. Nevertheless, they play a critical role, contributing information that is not available in the written text. For example, being able to hear the prolonged syllable length at the start of a new verse (or thought) facilitates the listener in following the meaning and structure of the poem. Also, the suspended completion of a word or phrase, as well as the intonation pattern, can signal to the audience that their vocal participation is invited.

A vital element of performance is also the 'performance arena' where words take on a special meaning. In this regard, Hymes (1962:19) argues that effective meaning depends on the form of the words interacting with a particular context. Foley (1995:9), building his notions on those of Lord $(1960,2000)$ and Bauman $(1977,1984)$, also argues for the importance of the context, claiming that it 'foregrounds the special metonymic, performance-based meaning selected by the situated "words"'. Malinowski (1926) agrees, claiming:

The text, of course, is extremely important, but without the context it remains lifeless. ... The whole nature of the performance, the voice and the mimicry, the stimulus and the response of the audience, mean as much to the natives as the text. (p. 24)

This latter dimension, the participation of the audience, is a critical component of the performance. They affirm

12.Oral features include lexical repetition (often exact rather than synonymous), use of redundancy, parallel syntactic constructions, colourful figurative language, alliteration, assonance, puns, word choice less specific, shorter sentences, alteration, assonance, puns, word choice less specific, shorter sentences, hythmic speech, short speaker, use of direct speech, use of gestures and facial expressions, a slower pace of presenting information, use of intonation, pitch, tempo, tone, pause and volume to express meaning, use of colloquial or dialectical speech, use of intensifiers and hyperbole (e.g. exclamations, ideophones and interjections), ellipsis and anacolutha (broken grammatical constructions), use of demonstrative words or particles, additive linkages and concrete contexts. 
(or otherwise) the performer, enabling him or her to continue. Moreover, it is the audience who determine the boundaries of fidelity of the text, based on their social, collective memory.

Every performance is unique in that the context is always different, as is the response and interaction of the audience. Variation in each performance of a particular text depends on the memory of the artist, but there is also intentional flexibility. The artist adapts the performance to the social occasion and the audience interaction. Klem (1982:121) claims that although there is a hard core of repeated information in oral art, variation (albeit controlled) is considered important for the sake of artistic expression. ${ }^{13}$

\section{Poetics}

Poetry 'characteristically foregrounds the phonic' (Wendland 2002:173). It is meant to be heard (Wendland 1998:188); in fact, some maintain that what is heard (in performance) is poetry. Dennis Tedlock (1972:221, 337) argues that all oral narrative is 'inherently poetic' in that it is organised in poetic lines, with each pause indicating a line change, as in written poetry.

Thus, in poetry, the unique features of aural art come into play. The ear is engaged and must discern patterns of sound, and pleasing sounds, which, in turn, may activate the other senses. Consequently, the translator of poetry must listen both to the sounds of the source text and the sounds of the receptor language, noting the sound play in the source text and seeking to provide sound play in the receptor language, for aesthetic and rhetorical effect.

In Bible translation, three aspects of the source text are in focus, viz. the content, form and function. As Wendland (2002:180) observes, 'No translation can reproduce all three elements of a text', and thus, according to the purpose of the work, special attention will be given to one over the other. With poetry, the focus could well be on the rhetorical function of the text, to move the hearer emotionally, and thus a higher level of literariness may be required than for a prose portion.

Therefore, to translate biblical poetry, the translator must be a poet. As Nasi (2016) notes: 'A poem is a movement ...' and the translator needs to capture the movement of the original. A translated poem is a new poem. The translator must be able to 'stretch' the receptor language in various poetic ways. This is largely an innate ability, although a person can be taught to recognise and utilise 'the principles of language manipulation' (Wendland 2004:68-70). Indeed, artists are both born and made (Nida \& Taber 1969:159), and thus, in my study, poets and musicians were invited to participate in some basic training to help them recreate biblical poetry using Zulu poetic form.

Zulu poetry and biblical poetry share several features; indeed, all poetic text tends to show two characteristics, viz. careful word choice and rhythm. Linton (1986:30) agrees when he argues that 'the minimum features of a literary text are rhythm and figurativeness'. Word choice and rhythm contribute to both the 'literary' and 'rhetorical' aspects of a literary-rhetorical translation.

An essential element of word choice is the use of metaphor, which often has a metonymic reference, one word calling up a whole context. For example, to refer to Shaka as uyingonyama is to draw in all the notions of royalty and majesty associated with 'the royal lion'. Other elements of word choice which contribute to the phonic dimension of the text are alliteration, word play, assonance and rhyme. Alliteration and assonance are frequent in Zulu poetry as they are inherent in the system of grammatical agreement. ${ }^{14}$ However, the natural alliteration is usually enriched by artificial alliteration, resulting in Zulu praise poetry being 'intensely alliterative' (Gunner 1990:195). For example, the izibongo [praise poem) of Dingane (Cope 1968:109, 1.303) includes the following line:

'l-si-dla-ngu-dla-ngu e-si-nje-nge-ndle-be ye-ndlo-vu' ('He is rough as the ear of an elephant' $).{ }^{15}$

The natural alliteration (resulting from the prefix si) is supported by artificial alliteration (dl- and ndl-).

With regard to the rhythm of a text, several features play a part; these include the repetition of words and sounds, the structure of the text (e.g. parallelism, chiasm, balanced lineation, terseness of expression) and the metrical pattern (or 'beat', based on stressed syllables, in the case of Hebrew and isiZulu). Lowes (1970:15) indicates several reasons for the importance of rhythm: it is essential to beautiful orature, it is an aid to memory and to oral performance and it naturally accompanies heightened speech.

One important component of the rhythm of a text is the repetition of words; there is often a redundancy of expression, but the repetition stirs the audience's emotions. For example, the izibongo of Shaka has the following cola (Cope 1968:96, lines 133, 134):

$$
\begin{array}{cl}
\text { Oth' esadl ezinye wadl' ezinye, } & \begin{array}{l}
\mathrm{He} \text { who while devouring } \\
\text { some, devoured others }
\end{array} \\
\text { Wath' esadl' ezinye wadl' ezinye. } & \begin{array}{l}
\text { And as he devoured others, he } \\
\text { devoured some more. }
\end{array}
\end{array}
$$

The organisational structure of a poem also contributes to the rhythm of the text, as does the construction of the poetic line. Such patterning also serves to delineate the boundaries of the text. As a result, the hearer is enabled to understand the text, enjoy it, remember it and become unified with the other hearers. Common structural patterns in poetry are parallelism, chiasm and terseness of style.

Parallelism is a common feature of both Zulu and biblical poetry. In Zulu poetry, it is used for its emotional impact, and

14.In isizulu, there are 13 noun classes, indicated by prefixes. Thus, the prefixes, along with concordial agreement patterns involving syntactically related words, can give a natural alliteration.

15.It is of interest that the comparison (for Dingane) is to the ear and not to the whole elephant. 'Elephant' and 'lion' are royal symbols, used often metonymically to refer to the great king, Shaka. 
to enhance the musical quality of the verse. For example, the Izibongo of Ndaba (Cope 1968:41) shows parallelism:

Obeyalala wangangemimfula,

Who when he lay down was the size of rivers,

Obeyavuka wangangezintaba

Who when he got up was the size of mountains

An example of threefold parallelism is apparent in the Izibongo of Senzangakhona (Cope 1968:77, lines 42-44), and is particularly interesting as Psalm 93:3 (one of the psalms in the study) uses similar threefold parallelism:
UMlunguzi wezingoje,
Peerer over precipices
Owalunguz' ingoje yomfowabo,
Who peered over the precipice of his brother
Owalunguz' ingoje kaZivalele.
Who peered over the precipice of Zivalele.

Chiasm is also a feature of some praise poems. Gunner (1990:195) notes that ordinary people often use this 'pattern of inversion', sometimes with a repetition of negative to positive. Contrast and balance are key features of Zulu oral art (Nyembezi 1954:21-24). The following example (Gunner 1990:195) shows this:

\section{Chopper down of the big tree;}

the little one falls on its own.

Berlin (1985) maintains that terseness of style is also an important characteristic of poetry. It is certainly apparent in both biblical and African poetry, and seems to serve several functions. Firstly, it contributes to the rhythm of the poem and thus to its aesthetics. And secondly, its metonymic character (using the hint of a theme to pull in a greater context) is semantically rewarding and stimulating for the audience.

\section{Ethnomusicology}

A characteristic of all African music is that it is integrated in the ordinary, everyday life of the people (Axelsson 1971:1), being an essential part of the community setting and cultural context (Chernoff 1979:36). ${ }^{16}$ One reason why music is so central to community life is that it is often the means of communicating important messages. This includes not only the communication of oral traditions, but also government messages may be transmitted in a musical form, to make them more accessible to the audience. ${ }^{17}$

A major purpose of music is to move the emotions of the hearer. Emotion is deeply intertwined with a particular song and melody, and the association remains, even if the words are changed. Thus, a new indigenous melody is needed for a new song, one that is free of any other associations. Another important function of music, particularly in African societies,

16.A Dan proverb (from Ghana) even says: 'The village where there is no musician is not a place where a man can stay'.

17.For example, drama and music were used to spread the message of HIV and AIDS among the people of Northern Mozambique. The government commissioned local groups to prepare songs, dance and drama to carry the message to the people. is its collective and communal power (Sacks 2007:244, 247). A community clapping or moving in synchrony is bound together by the rhythm, which all present internalise. A further benefit of music is to allow people to organise and hold a large amount of information in the mind. ${ }^{18}$

Axelsson (1971:vi) claims that 'African music is first and foremost vocal in style. Almost no music is performed without singing'. Nketia (1974:244) asserts that vocal music is emphasised in African music because singing provides the greatest opportunity for people to participate in group events.

Most researchers seem to agree about the structure of African songs. The most common form is responsorial, with a song leader initiating and maintaining the song (Swartz 1956:29-31), and the 'response' repeating the material sung by the soloist. The antiphony may arise from two choirs alternating, or with a soloist and chorus alternating.

Early researchers ${ }^{19}$ considered that harmony was a foreign import, but African researchers (such as Bongani Mthethwa and Caesar Ndlovu) have more recently argued that harmony is an integral part of indigenous African music. Mthethwa (1988:31) says: 'I would like to dispel the notion that harmony is a Western invention'. He claims that both African and European music have harmony, melody and rhythm, but differ in their relative importance: Europeans focus on harmony and Africans on rhythm.

African music is derived from language (Chernoff 1979:75); thus, both rhythms and melodies are constrained by the dimensions of language. Moreover, most African languages are tonal (Greenberg 1966), that is, certain syllables carry pitch that is high, low, medium, rising or falling. Thus, an African composer will find it difficult to write a rising melody when the words have a falling intonation (Chernoff 1979:80).

It is generally agreed that the most significant feature of African music is its rhythm (Axelsson 1971:19). Chernoff (1979:23) maintains that rhythm is 'the most perceptible' but 'least material thing'. Ronald Rassner (1990:244) concurs: 'An audience feels a performance through rhythm'. However, although rhythm is the dominant feature of African music, it is easily misunderstood by westerners, for whom the sensibility of rhythm is secondary in emphasis and complexity to harmony and melody (Chernoff 1979:42).

In poetry, there are two kinds of rhythm, viz. sound rhythm (produced by sound effects, such as alliteration and assonance) and poetic rhythm (produced by structures such as parallelism and chiasm, as well as terseness). The third type of rhythm in oral art is musical rhythm, which is produced by the voice or instruments (including hands and feet).

18.Sacks (2007:237) claims that the most powerful mnemonic devices are rhyme, metre and song.

19.For example, Swartz, Axelsson. 
The notion of metre and rhythm in African oral art is extremely complex. Dargie (1991) notes further that:

it can be very difficult for Western musicians to master the performance of traditional African music, with its complexity of rhythm, its scales unusual to Western ears, and its difficulty of adaptation to European languages. (p. iv)

For the (western) Bible translator, who is not necessarily a musician, the goal of producing a singable translation of a psalm in an African language, using African rhythm, can seem overwhelming. However, an understanding of the features of African music can provide some guidance and cautions, so that the errors of the past can be avoided.

\section{Application of results to the church's ministry}

One of the audience members who was interviewed at the church performance was the visiting preacher for that day. He noted that the performance of the psalms before his preaching prepared the congregation to receive his message. It did so through providing a refreshing, enlivening interlude in the normal programme of sitting listening to someone speaking. How much more advantageous could this be if the performance item were based on the text for the preaching? The song would then reinforce the message, and be remembered long after the service had ended.

Songs, through the repetition of the chorus, and the use of rhythm, enable listeners to remember the content so much better than that which is just spoken. The use of rap, or spoken poetry, in combination with song, proved to be a pleasing aesthetic experience, with the variety of voice and texture adding to the experience. Most of the young people in the audience jumped up to take videos on their phones of their friends performing. And although the audience did not join in with the singing, ${ }^{20}$ there was loud applause, and ululating, indicating the items were well received.

This then is a possibility: to use oral art performance to complement the preaching of the Word in the Sunday services. Just as one has a choir to render a musical item, a drama or poetry or music group could render the Scripture message. Even if it were simply a spoken poetry version of a fresh meaning-based translation, it could make a significant difference to the understanding and interest of the community.

A second application of this 'community-based approach to Bible translation' is in terms of personal discipleship. The youth leader or pastor of a church could work with interested members, and equip them to make their own translations of selected portions of biblical text, once they had together studied the portion, considered translation principles and poetic or oral features. If participants were then encouraged to perform their translations, this would provide further

20.This was possibly as they were unsure if that were acceptable (being a special performance) and because the songs were new, and were being heard for the first time. They have since repeated some of the items, and the audience has joined in to some extent. opportunity to explore 'translation in performance' and insights that arise as one performs the text.

In the empirical study, family commitments precluded a number of interested youth from participating. Thus, the idea is posited to establish an online platform where interested persons could learn about translation and poetics, and post their own translations (and possibly video performances). Comments from others would allow for discussion of key terms, and participants would be enabled to interact directly with the 'source' text and translation issues. ${ }^{21}$ The sense of ownership and participation in the translation, even if it is not 'perfect', seems to far outweigh the value of having a professional translation. This is not to say that individual translations would replace the definitive (published) versions, but they would provide a highly relevant and personally owned version that is likely to significantly impact the individual as he or she works through it. ${ }^{22}$ It would also enable the various dialects ${ }^{23}$ to be represented and enjoyed, with participants learning from each other and appreciating the variety and depth of vocabulary in their language. This idea is currently in a trial stage with encouraging results.

\section{Conclusion}

The world is changing so fast that many of the techniques and programmes that worked in the past are now obsolete. On the other hand, there are new potential-packed opportunities to communicate powerfully with people. Community-based translation and performance of the Scriptures is one such innovation for the church to grasp, promising significant gains for the preaching and discipleship ministries.

Bible translators and church leaders should work together in the next few years to make this a reality. Bible teachers with some understanding of translation could encourage young people to explore reference materials, make their own translations and perform them for their peers. The danger of miscommunication is slight (but rectifiable), whereas the danger of non-communication, a present reality in many situations, looms large.

As Rowe (1999:63) notes: 'We are the translators and communicators not of God's book, but of God's Word'. Is it not worth exploring every avenue to communicate his Word effectively?

\section{Acknowledgements Competing interests}

The author declares that she has no financial or personal relationship(s) that may have inappropriately influenced her in writing this article. 21.My Zulu research assistant noted that young Zulus have 'no idea of where the
(1959) translation came from. It is just one of the many things they have no control
over'.

22.See the encouraging and visionary work of Shirky (2010).

23.More work is needed to distinguish if dialects are regionally-based or age-based. 


\section{References}

Axelsson, O., 1971, African music and European Christian mission, Uppsala Universitet Uppsala, Sweden.

Bauman, R., 1977/1984, Verbal art as performance, Waveland Press, Prospect Heights, IL.

Berlin, A., 1985, The dynamics of biblical parallelism, Indiana University Press, Bloomington, IN.

Chernoff, J.M., 1979, African rhythm and African sensibility, University of Chicago Press, Chicago, IL.

Cope, A.T., 1968, Izibongo Zulu praise poems, Oxford University Press, London.

Dargie, D., 1991, Lumko hymnbook. African hymns for the Eucharist, Lumko Institute, Delmenville.

de Waard, J. \& Nida, E.A., 1986, From one language to another: Functional equivalence in Bible translating, Thomas Nelson, Nashville, TN.

Dickie, J.F., 2017, 'Zulu song, oral art, performing the Psalms to stir the heart', Unpublished PhD thesis, Biblical Studies, University of KwaZulu-Natal, South Africa, viewed 12 October 2017, from https://www.academia.edu/31091578 or http://researchspace.ukzn.ac.za/handle/10413/14223

Foley, J.M., 1995, The singer of tales in performance, Indiana University Press, Bloomington, IN.

Fry, E.M., 1999, 'Faithfulness: A wider perspective', in P. Soukup \& R. Hodgson (eds.) Fidelity and translation. Communicating the Bible in new media, pp. 7-29, American Bible Society, New York.

Greenberg, J.H., 1966, The languages of Africa, 2nd edn., Indiana University Press, Bloomington, IN.

Gunner, E., 1990, 'Wand or walking stick? The formula and its use in Zulu praise poems', in I. Okpewho (ed.), The oral performance in Africa, pp.185-207, Spectrum Books Ltd., Ibadan, Nigeria.

Gutt, E.-A., 1992, Relevance theory: A guide to successful communication in translation,: SIL and UBS, Dallas, TX.

Hargreaves, C., 1993, A translator's freedom: Modern English Bibles and their language, JSOT Press, Sheffield.

Hymes, D., 1962, 'The ethnography of speaking', in T. Gladwin \& W. Sturtevant (Eds.) Anthropology and Human Behaviour, pp.13-53, Anthropological Society of Washington, Washington DC.

Klem, H.V., 1982, Oral communication of the scripture. Insights from oral art, William Carey Library, Pasadena, CA

Linton, C., 1986, 'The importance of literary style in Bible translation today', in K. Barker (ed.), The NIV: The making of a contemporary translation, pp. 15-31, Zondervan, Grand Rapids, MI.

Lord, A.B., 1960/2000, The singer of tales, Harvard University Press, Cambridge, MA.

Loubser, J.A.B., 2004, 'How do you report something that was said with a smile? - Can we overcome the loss of meaning when oral-manuscript texts of the Bible are represented in modern printed media?', Scriptura 87, 296-314. https://doi. org/10.7833/87-0-967

Lowes, J.L., 1970, 'The noblest monument of English prose', in D.G. Kehl (ed.), Literary style of the Old Bible and the new, Bobbs-Merrill, Indianapolis, IN.

Lundin, R., Thiselton, A.C. \& Walhout, C., 1999, The promise of hermeneutics, Eerdmans, Grand Rapids MI.

Malinowski, B., 1926, Myth in primitive psychology, Norton, New York.

Maxey, J.A., 2009, From orality to orality: A new paradigm for contextual translation of the Bible, Biblical Performance Criticism Series 2, Cascade Books, Eugene, OR.

Mthethwa, B., 1988, 'The songs of Alfred A. Kumalo: A study in Nguni and Western musical syncretism', Papers presented at the 6th Symposium of Ethnomusicology, Rhodes University, Grahamstown, International Library of African Music, pp. 28-32.
Munday, J., 2001/2010, Introducing translation studies. Theories and applications, Routledge, New York.

Nasi, F., 2016, 'Extreme texts, extreme translations', Paper delivered at Nida School of Translation Studies, Misano, Italy, 30th May-10th June.

Nida, Eugene A., 1960, Message and mission: The communication of the Christian faith, Harper, New York.

Nida, E.A., 1964, Towards a science of translating: With special reference to principles and procedures involved in Bible translating, Brill, Leiden.

Nida, E.A., 2003, Fascinated by languages, John Benjamins, Amsterdam.

Nida, E.A. \& Taber, C.R., 1969, The theory and practice of translation, Brill, Leiden.

Nketia, J.H.K., 1974, The music of Africa, W.W. Norton, New York.

Nord, C., 1988, Textanalyse und Übersetzen, Theoretische Grundlagen, Methoden und didaktische Anwendung einer übersetzungsrelevanten Textanalyse, Julius Groos, Heidelberg, Germany.

Nyembezi, C.L.S., 1954, Zulu proverbs, Witwatersrand University Press, Johannesburg. Ong, W., 1982, Orality and literacy: The technologizing of the word, Methuen, London.

Rassner, R.M., 1990, 'Narrative rhythms in AGiryama Ngano: Oral patterns and musical structures', in I. Okpewho (ed.), The oral performance in Africa, pp. 228-247, Spectrum Books Ltd., Ibadan, Nigeria.

Reiss, K., 1984, Groundwork for a general theory of translation, Niemeyer, Tubingen, Germany.

Rhoads, D., 2012, 'The art of translating for oral performance', in J. Maxey \& E.R. Wendland (eds.), Translating scripture for sound and performance, pp.22-48, Cascade Books, Eugene, OR.

Rowe, G.R., 1999, 'Fidelity and access: Reclaiming the Bible with personal media', in P.A. Soukup \& R. Hodgson (eds.), Fidelity and translation. Communicating the Bible in new media, pp.47-63, American Bible Society, New York.

Sacks, O., 2007, Musicophilia - Tales of music and the brain, Picador, Britain.

Scott, B.B., 1999, 'A new voice in the Amphitheater: Full fidelity in translating', in P.A. Soukup \& R. Hodgson (eds.), Fidelity and translation. Communicating the Bible in new media, pp. 101-118, American Bible Society, New York.

Scribner, S. \& Cole, M., 1981, The psychology of literacy, Harvard University Press, Cambridge, MA.

Shirky, C., 2010, Cognitive surplus. Creativity and generosity in a connected age, Penguin Press, New York.

Sperber, D. \& Wilson, D., 1986, Relevance: Communication and cognition, Harvard University Press, Cambridge.

Swartz, J.F.A., 1956, 'A Hobbyist looks at Zulu and Xhosa songs', Journal of African Music 1(3), 29-33. https://doi.org/10.21504/amj.v1i3.311

Tedlock, D., 1972, Finding the center: Narrative poetry of the Zuni Indians, Dial, New York.

Vermeer, Hans J., 1989, Skopos and commission in translational action: Readings in translation theory, Oy Finn Lectura Ab, Helsinki.

Wendland, E.R., 1998, Buku Loyera. An introduction to the Chichewa Bible Translation (Kachere Monograph No.6), Malawi, CLAIM.

Wendland, E.R., 2002, 'Towards a "Literary" translation of the scriptures: With special reference to a 'poetic' rendition', in J.A. Naude \& C.H.J. Van der Merwe (eds.), Contemporary translation studies and Bible translation, A South African perspective, Acta Theologica Suppl. 2, pp.164-201, UFS, Bloemfontein.

Wendland, E.R., 2004, Translating the literature of scripture, SIL, Dallas, TX.

Wendland, E.R., 2006, LiFE-style translating, SIL, Dallas, TX.

Wendland, P., 2012, 'Bible translations for the 21st century,' Reformation Lectures (unpublished), Wisconsin Lutheran Seminary, Mequon, Wisconsin.

Weschler, R., 1998, Performing without a stage. The art of literary translation, University of Texas, Dallas, TX. 